\title{
An anatomopathological study of hepatic coccidiosis (Calyptospora sp.) in the Acará-pixuna, Aequidens plagiozonatus Kullander, 1984 from the Brazilian state of Pará
}

\author{
[Estudo anatomopatológico de coccidiose hepática (Calyptospora sp.) em Acará-pixuna, Aequidens \\ plagiozonatus Kullander, 1984, no Brasil, estado do Pará]

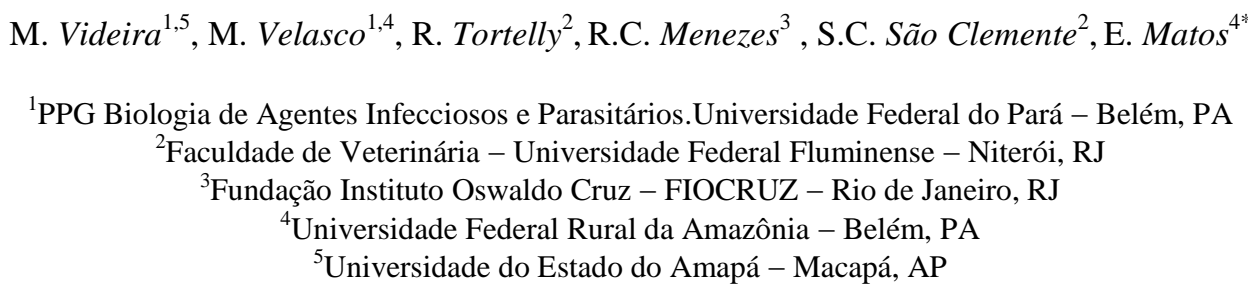

\begin{abstract}
The present study focuses on the anatomopathological alterations provoked by parasitism by Calyptospora sp. in 40 specimens of Aequidens plagiozonatus collected in Pará, Brazil. Examinations of the fresh material by compression of the hepatopancreas and histological sections showed immature forms and oocysts characteristic of the genus Calyptospora, in addition to a large quantity of melanomacrophagic centers spread throughout the organ. No significant inflammation of the hepatic tissue was observed. The melanomacrophagic centers and the compression of the hepatocytes are part of the response of the host to the parasite. This study represents the first record of parasitism by Calyptospora in A. plagiozonatus.
\end{abstract}

Keywords: fish, acará-pixuna, parasite, coccidio, Calyptospora, pathology

\section{RESUMO}

Descreveram-se as alterações anatomopatológicas provocadas pelo parasitismo por Calyptospora sp. em 40 espécimes de Aequidens plagiozonatus, provenientes do município de Peixe-boi, Pará, Brasil. Foram encontradas formas imaturas e oocistos característicos do gênero Calyptospora, nos exames frescos por compressão e cortes histológicos, além de um grande número de centros melanomacrofágicos dispersos por todo o órgão. Digna de nota foi a ausência de inflamação significativa no tecido hepático. Centros melanomacrofágicos e compressão dos hepatócitos estão envolvidos na resposta do hospedeiro ao parasito. Este é o primeiro registro de ocorrência de parasitismo por Calyptospora sp. na espécie estudada.

Palavras-chave: peixe, acará-pixuna, parasita, coccidio, Calyptospora, patologia

\section{INTRODUCTION}

The acará-pixuna (Aequidens plagiozonatus Kullander, 1984) was first described from the River Plate basin in Paraguay. This fish feeds on small crustaceans and smaller fish, and, like other cichlids, is relatively aggressive. Its main characteristics are its distinct parental care

Recebido em 12 de agosto de 2011

Aceito em 25 de agosto de 2012

*Autor para correspondência (corresponding author)

E-mail: edilson.matos@ufra.edu.br behavior, attractive colors, and small size, all of which contribute to its increasing popularity as an ornamental fish (Kullander, 2006).

The phylum Apicomplexa Levine, 1970, is a group of micro-organisms which includes pathogenic and parasitic forms that occur in a wide variety of organisms, including bivalve mollusks and fish (Matos et al., 2004). The 
parasites of this phylum found in Amazonian fish include Calyptospora spinosa (Calyptosporidae), found in the liver of the Jacundá, Crenicichla lepidota (Azevedo et al., 1993/1995), Calyptospora tucunarensis in Cichla ocellaris, the speckled peacock bass (Bekesi and Molnar, 1991), and Calyptospora sp. in the Pirarucu, Arapaima gigas (Bonar, 2006).

Spores of the coccidian Calyptospora sp. can be observed under light microscopy, infesting the liver, forming oocysts with four sporocysts, each containing two sporozoites. Cells in different stages of the life cycle are commonly observed, in some cases forming parasitophorous vacuoles, with rounded to elliptical sporozoites visible under transmission electron microscopy (Azevedo et al., 1993).

Histopathological studies may provide useful insights into the principal and secondary causes of diseases in fish populations, with the aim of evaluating the impacts on the tissue, biochemistry, physiology, behavior or metabolism of these aquatic organisms resulting from their exposure to external agents (Teixeira, 2008). The present study describes the anatomopatological effects provoked by the parasitism of $A$. plagiozonatus by Calyptospora.

\section{MATERIAL AND METHODS}

A total of 40 specimens of $A$. plagiozonatus were collected in the municipality of Peixe-Boi $\left(01^{\circ} 07^{\prime} 17.65^{\prime \prime} \mathrm{S}, \quad 47^{\circ} 18^{\prime} 48.35^{\prime \prime} \mathrm{W}\right)$ in the Brazilian state of Pará. The specimens had a mean total length of $13.4 \pm 1.5 \mathrm{~cm}$, and mean weight of $66.0 \pm 19.2 \mathrm{~g}$. They were captured using cast nets and gillnets. Following the collection of biometric data, the animals were anesthetized with MS222 (Sigma), and then necropsied for the detailed examination of their internal organs.

Liver fragments were set in a fresh preparation between slide and coverslip for examination. When parasitism was confirmed, the liver was fixed in Davidson solution $(95 \%$ ethanol, formaldehyde and acetic acid, distilled water), and processed using the standard techniques for setting in paraffin, staining with hematoxylin and eosin and Gutierrez's trichrome for examination. The specimens were photographed under a Zeiss Primo Star microscope coupled to a Canon A610/A620 52mm camera.

\section{RESULTS AND DISCUSSION}

The prevalence of infection by Calyptospora in A. plagiozonatus was $35.2 \%$. Under optical microscopy, Calyptospora oocysts (with four sporocysts) were observed forming parasitic vacuoles (Figure 1A), in addition to immature forms (Figure 1B). These vacuoles were found throughout the livers of the infected specimens, and in the intra-hepatic pancreatic tissue, or exocrine pancreas, in the complex known as the hepatopancreas (Figure 1C).

Macroscopically, the coloration of the livers varied from pale whitish to darker superficial areas. The lighter coloration was observed in the livers in which Calyptospora oocysts were identified microscopically. These mature oocysts were relatively rare, and were found in local agglomerations, within a well-defined area delimited by an acidophilic wall. These morphological features were observed in $35 \%$ of the infected specimens.

These areas of darker coloration in the livers were rich in immature coccidians. The histopathological analysis revealed the presence of a large number of melanomacrophagous centers widely distributed throughout the organ. These centers are very dark in color, varying from chesnut-yellow to brown (Figure 1C), and were common in $65 \%$ of the infected specimens analyzed.

Cheung et al. (1986) observed that infections with Calyptospora in redeye piranha, Serrasalmus niger, caused a variety of lesions, including grayish blemishes on the hepatic lobes, visible macroscopically, which were consistent with the features observed in the present study. It is interesting to note that, in the present study, melanomacrophagic centers were also observed throughout the hepatopancreas of a specimen of A. plagiozonatus that was not infected with coccidians. Flores-Lopes and Malabarba (2007) recorded these centers in a variety of sizes and concentrations, coated externally with a thin layer of conjunctive tissue and melanin pigments, as observed in the present study (Figure 1D). 

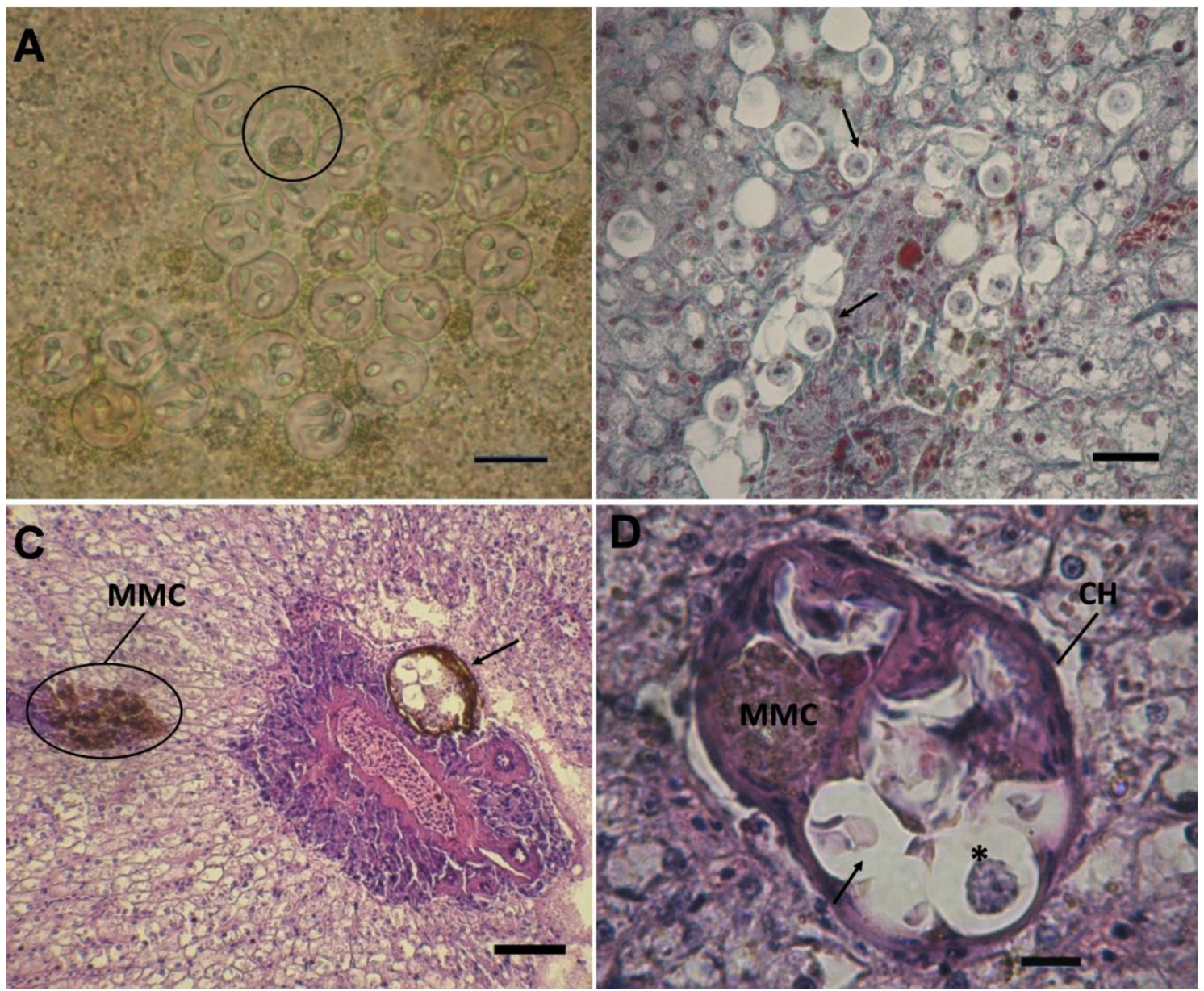

Figure 1. Aequidens plagiozonatus. Hepatopancreas. Calyptospora sp. Oocysts A- Predominance of mature sporocysts (arrow) observed in a fresh preparation under optical microscopy. Note the presence of an immature sporocyst (circled). B- Immature sporocysts located among the hepatocytes (arrow) (Gutierrez trichromatic stain). C- Oocyst (arrow) located in the hepatopancreas. Note the presence of the melanomacrophagic centers (MMC). (HE stain). D- Oocyst containing mature (arrow) and immature $(*)$ sporocysts, a hyaline capsule (HC) and melanomacrophagics centers (MMC). Scale: $20 \mu \mathrm{m}$.

In fish, these melanomacrophagic centers are normally found in the hepatic tissue (Manera et al., 2000), and are made up of cells full of dark chestnut pigmentary granules, as observed under routine (HE) staining. An excess of these bodies may indicate an inflammatory reaction of the cells, the processing of antigens and/or exposure to an external agent. Some authors have also proposed that these bodies may be useful as bioindicators of environmental pollution or degradation (Couillard and Hodson, 1996).

Agius and Roberts (2003) interpreted the melanomacrophagic centers as depositories for resistant pathogens and parasitic spores. Some studies have also shown that these centers are associated with elevated resistance to mycobacteria and parasites of the genus Myxobolus (Roberts, 2001), and this was confirmed in the present study, although in this case, the features enveloped the Calyptospora oocysts (Fig. 1D). In some cases, in addition to the mature sporocysts, unsporulated oocysts were observed dispersed among the hepatocytes, or even grouped among the hepatic cells.

Azevedo et al. (1993) described alterations caused by Calyptospora in fish, observed using transmission electron microscopy, including nuclear hypertrophy and the destruction of the 
cytoplasm of the host's cells. Békesi and Molnar (1991) also observed degradation of the liver in histological sections. However, the agglomerations of parasites observed in the present study rarely provoked a marked response in the host, but rather a slight compression of the hepatocytes adjacent to the location of the parasite. This is consistent with the findings of Bonar et al. (2006), who noted an absence of any significant inflammation of the hepatic tissue infected by Calyptospora in Arapaima gigas.

The results of the present study indicate that the melanomacrophagic centers are involved in the response of the host to the parasite. This is the first record of parasitism by Calyptospora in $A$. plagiozonatus.

\section{ACKNOWLEDGMENTS}

The authors are grateful to CAPES and CNPq.

\section{REFERENCES}

AGIUS, C.; ROBERTS, R.J. Melanomacrophage centres and their role in fish pathology. J. Fish Dis., v.26, p.499-509, 2003.

AZEVEDO, C.; MATOS, P.; MATOS, E. Morphological Data of Calyptospora spinosa n. sp. (Apicomplexa, Calyptosporidae) Parasite of Crenicichla lepidota HEÒKEL, 1840 (Teleostei) from Amazon River. Eur. J. Protistol.,v.29, p.171-175, 1993.

AZEVEDO, C.; MATOS, P.; MATOS, E. Ultrastructural data on sporogony of the coccidian parasite Calyptospora spinosa from the liver of the Amazonian fish, Crenicichla lepidota Heckel. J. Fish Dis., v.18, p.475-79, 1995.

BÉKÉSI, L.; MOLNAR, M. Calyptospora tucunarensis n. sp. (Apicomplexa: Sporozoea) from the liver of Tucunaré Cichla ocellarís in Brazil. Syst. Parasitol., v.18, p.127-132, 1991.

BONAR, C.J.; POYNTON, S.L.; SCHULMAN, F.Y. et al. Hepatic Calyptospora sp (Apicomplexa) infection in a wild-born, aquarium-held clutch of juvenile arapaima Arapaima gigas (Osteoglossidae). Dis. Aquat. Org. , v.70, p.81-92, 2006.
CHEUNG, P.J.; NIGRELLI, R.F.; RUGGIERI, G.D. Calyptospora serrasalmi sp.nov. (Coccidia: Calyptosporidae) from liver of the Black piranha, Serrasalmus niger Schomburgk. J. Aquat. Sci., v.4, p.54-57, 1986.

COUILLARD, C.M.; HODSON, P.V. Pigmented macrophage aggregates: a toxic response in fish exposed to bleached-kraft mill effluent? Environ. Toxicol. Chem., v.15, p.1844-1854, 1996.

FLORES-LOPES, F.; MALABARBA, L.R. Alterações histopatológicas observadas no fígado do lambarí Astyanax jacuhiensis (cope, 1894) (Teleostei, Characidae) sob influência de efluentes petroquímicos. Biociências, v.15, p.166-172, 2007.

KULLANDER, S.O. Cichlid Fishes from the La Plata Basin. Part V. Description of Aequidens plagiozonatus sp. n. (Teleostei, Cichlidae) from the Paraguay River. Syst. Zool. Scr., v.13, p.155159, 1984.

KULLANDER, S.O. Ichthyological Exploration of Freshwaters: An international journal for field-orientated. Ichthyology., v.17, p.289-398, 2006.

MANERA, M.; SERA, R.; ISANI, G.; CARPENÉA, E. Macrophage aggregates in gilthead sea bream fed copper, iron and zinc enriched diets. J. Fish Biol., v.57, p.457-465, 2000 .

MATOS, E.; CASAL, G.; MATOS, P. et al. Microrganismos Parasitos de Animais Aquáticos da Amazônia. In: RANZANI-PAIVA, M.J.T.; TAKEMOTO, R.M.; LIZAMA, M.A.P. Sanidade de organismos aquáticos. São Paulo: Editora Varela, p.158-178, 2004.

ROBERTS, R.J. Fish Pathology, 3rd ed. Philadelphia: W.B. Saunders, PA. p.96, 2001.

TEIXEIRA, P.A.N. Avaliação da histopatologia hepática em boga (Chondrostoma polylepis) e barbo (Barbus bocagei) capturados no Rio Vizela. 2008. 54f. Dissertação (Mestrado em Tecnologia Ambiental) Universidade de Trás-dos-Montes e Alto Douro. 